\title{
Expectation of students from their teachers in undergraduate Medical Education in selected Medical Colleges in Bangladesh
}

\author{
Dr. Brigadier General Md Abdus Sabur Miah ${ }^{1}$, Professor Dr. Md. Humayun Kabir Talukder ${ }^{2}$
}

\begin{abstract}
Introduction: An important aspect in higher education consists in improving the quality of students outcomes. Infact, different factors influence these outcomes. Among these factors are the quality of teaching, material used and at the students' expectation of the institution. Part of this perception is reflected in what students expect from their teachers. It is fact that students' performance depends on teachers' exigencies, teachers' perception of students' expectations and how the teachers fit with these expectations.
\end{abstract}

Methodology: It was a cross sectional type of descriptive study. Conducted in 3 medical colleges for one year (July 2012 to June 2013) with the aim to find out the expectations of students from their teachers in undergraduate medical education in Bangladesh. The total respondents were 353 students selected by convenience sampling from preclinical, para clinical and clinical departments of those medical colleges. Pre-tested, self administered, structured anonymous using English \& Bengal, Questionnaire, with Likert scale was used for data Collection. Comparison of expectation level between male \& Female students, among the medical colleges were done by applying unpaired test.

Results: 353 medical students of three selected medical colleges participated in this study. Among them 52\% were female \& 48\% were male and 94\% were Muslim and 6\% were Hindu. There were 30 statement on students' expectations. Respondent expressed their views as expected and highly expected in all the statements. Regarding teaching, Teacher will be sincere, knowledgeable, will conduct class with adequate preparation. Punctual, teaching time will be used properly and will give explanation \& example for better understandings' 92-97\% students expressed their view as expected and highly expected.

In interpersonal relation \& in using modern instructional materials by the teachers $92-98 \%$ students expressed expected and highly expected.

It is revealed that expectation on this 30 statement, students expectations are very high. So it is significant to address these issues by the teachers and administrator.

Conclusion: It is revealed in the study that expectation of students from the selected three Medical Colleges were similar and no significant variations were found, students started their journey in Medical education with some expectation but all expectations which might not be perfect. But the students' expectation which they had in the study was the reflection of all the students of under graduate medical education in Bangladesh.

Key Words: Expectation of Students From Their Teachers in Undergraduate Medical Education

\section{Introduction}

Medical profession has witnessed tremendous changes in the last four decades. These expectations are now of greater complexity and a different order to those which might have applied in the past.

Medical colleges now find themselves brings pushed on the one hand to mounting student expectations, while on the other hand there are fears that the fundamental purpose of education could be distorted or even lost if institutions go to far in the direction of placing education on a commercial

${ }^{i}$ Dr. Brigadier GeneralMd Abdus Sabur Miah, Student of MMEd, CME, Mohakhali, Dhaka-1219.

${ }^{2}$ Professor (Curriculum Development \& Evaluation), CME, Dhaka.

Contact Address: NAM Village Appartment, House No. A-10, Road No. 23, Block\#B, Banani, Dhaka-1212 footing.

A student may be satisfied with some expectations of his/her medical education but at the same time may be unhappy with other expectations related to teaching, interperson relationship \& educational environment. For medical students intrinsic satisfaction on their expectation can came from class room activities, daily interaction with teachers, students, and learning from the teaching.

The 1980s and 90s were very much a period of change. This changed the face of higher education with the advent of new technology the society is also changing with newer expectations \& needs. Students of new generation are entering in higher education especially in medical education with a new set of expectations.

The trend of globalization, change in our higher education

Bangladesh Journal of Medical Education 2012;3(1):12-17. C 2012 Miah et al., publisher and licensee Association for Medical Education. This is an Open Access article which permits unrestricted non-commercial use, provided the original work is properly cited. 
system, the demands and aspirations of the society and the increased need for continuous and life long learning are forcing the new generation of students to become autonomous and reflective Learner and has increased the need of the teachers to understand the students' expectations. The purpose of teaching is to enable Learning and to do so teacher must understand what the students' expect from them and how these could be addressed.

\section{Methodology}

IIt was a cross sectional type of descriptive study, conducted in 03 medical Colleges for one year (July 2012 to Jun 2013). Total respondents were 353 students selected by convenience sampling. Studying in preclinical, paraclinical and clinical departments of those medical colleges.

Pre-tested, self-administered, structured, anonymous, using English questionnaire, with likert scale was used for data collection. This approach produced a pool of 30 items. 30 items were included in the structured questionnaires.

Each of the 30 items had 5-point likert response categories from highly expected $=5$ to highly unexpected $=1$ score. In likert scale score 3 is for undecided. Score more than 3 was perceived as expected and less than 3 was perceived as unexpected.

All the collected data were checked manually. Data editing, entry, processing and analysis were done by using 15 version of SPSS. For clear understanding at the results A B and $\mathrm{C}$. related items were grouped under individual fact.
Facct-A. Students' expectations from their teachers in relation to teaching, which contains 17 characteristics (Items)

Facct-B. Students' expectations from their teachers in relation to interpersonal relationship. Which included 8 items.

Facet-C. Students' expectations from this teachers in relation to use of instructional material by the teachers which includes 5 items.

Comparison of expectation level between male and Female students, students Studying in those medical Colleges.

There were no ethical problem because all the information were collected anonymously with prior permission of the authority and the participants gave their opinion Voluntarily. Researcher maintained confidentiality in all cases.

\section{Results}

Table 1: Distribution of the respondents as per Medical Colleges

$(\mathrm{n}=353)$

\begin{tabular}{|l|c|c|}
\hline Name of College & Frequency & Percent \\
\hline Sir Salimullah Medical College & 111 & 31.44 \\
\hline Armed Forces Medical College & 118 & 33.43 \\
\hline $\begin{array}{l}\text { Hossain Shaheed Sorwardy } \\
\text { Medical College, Dhaka }\end{array}$ & 124 & 35.13 \\
\hline
\end{tabular}

Table I Show distribution of respondents as per the medical colleges. Out of 353 respondents 111 (31.44\%) were from Sir Salimullah Medical College Dhaka, 118 (33.43\%) were from Armed Forces Medical College, Dhaka and 124 (35.13\%) were from Hossain Shaheed Sorwardi Medical College, Dhaka.

Table 2 A: Distribution of the respondent by their opinion on the statements regarding expectations of students from their teachers in relation to teaching

\begin{tabular}{|c|c|c|c|c|c|}
\hline \multirow{2}{*}{$\begin{array}{l}\text { Statements regarding students' } \\
\text { expectations from their teachers } \\
\text { in relation to teaching }\end{array}$} & \multicolumn{5}{|c|}{ Level of Expectation } \\
\hline & $\begin{array}{l}\text { Highly Unexpected } \\
(\%)\end{array}$ & $\begin{array}{l}\text { Unexpected } \\
(\%)\end{array}$ & $\begin{array}{l}\text { Undecided } \\
(\%)\end{array}$ & $\begin{array}{l}\text { Expected } \\
(\%)\end{array}$ & $\begin{array}{l}\text { Highly Expected } \\
(\%)\end{array}$ \\
\hline $\begin{array}{l}\text { All teachers will be sincere in } \\
\text { imparting teaching }\end{array}$ & $6(1.7)$ & $1(.3)$ & - & $83(23.5)$ & $263(74.5)$ \\
\hline $\begin{array}{l}\text { Teachers should be knowledgeable } \\
\text { about their respective subject }\end{array}$ & $2(.6)$ & $1(.3)$ & - & $71(20.1)$ & $279(79)$ \\
\hline $\begin{array}{l}\text { Teachers should have good and } \\
\text { adequate preparation for conduction } \\
\text { of class }\end{array}$ & $1(.3)$ & - & $6(1.7)$ & $113(31.9)$ & $233(66.1)$ \\
\hline $\begin{array}{l}\text { All teachers will take class in time as } \\
\text { per routine/ schedule }\end{array}$ & $7(2.0)$ & $7(2)$ & $13(3.7)$ & $184(52.1)$ & $142(40.2)$ \\
\hline $\begin{array}{l}\text { Teachers will use teaching time } \\
\text { properly }\end{array}$ & $3(.9)$ & $10(2.9)$ & $13(3.7)$ & $159(45.4)$ & $165(47.1)$ \\
\hline $\begin{array}{l}\text { Teacher will give explanation and } \\
\text { example for better understanding of } \\
\text { students }\end{array}$ & $2(.6)$ & $1(.3)$ & $5(1.4)$ & $104(29.5)$ & $241(68.3)$ \\
\hline
\end{tabular}

Bangladesh Journal of Medical Education 2012;3(1):12-17. 
Table 2 A: Shows that regarding statement "sincerity in imparting Teaching" were highly expected by 263 (74.5\%) respondents and expected $83(23.5 \%)$ respondents. Only few $6(1.7 \%) \& 1(.3 \%)$ respondents expressed highly unexpected and unexpected respectively.

Regarding issue "knowledgeable about respective subjects by the teachers" respondents (353) expressed highly expected $279(79 \%)$, expected $71(20.1 \%)$ and only $2(.6 \%)$ $\& 1(.3 \%)$ expressed highly unexpected and unexpected respectively which is very negligible.

Regarding statement "Teachers should have good and adequate preparation for conducting class", $223(66.1 \%)$ respondent expressed highly expected and 123 (31.9\%) expressed expected.
On the issue "All teachers will take classes in time as per routine" $184(52.1 \%)$ respondents expressed expected and $142(40.2 \%)$ expressed highly expected and remaining expressed unexpected and highly unexpected.

On the issue regarding use of teaching time $165(47.1 \%)$ respondent expressed highly expected and 159(45.4\%) expressed expected and remaining expressed unexpected and highly unexpected.

Regarding issue on "Teacher will give explanation and example for better understanding of students" $241(68.3 \%)$ respondents expressed highly expected and 104(29.5\%) expressed expected.

Table 2 B: Distribution of the respondent by their opinion on the statements regarding expectations of students from their teachers in relation to teaching

\begin{tabular}{|l|c|c|c|c|c|}
\hline $\begin{array}{l}\text { Statements regarding students' } \\
\text { expectations from their teacher } \\
\text { in relation to teaching }\end{array}$ & $\begin{array}{c}\text { Highly Unexpected } \\
\text { (\%) }\end{array}$ & $\begin{array}{c}\text { Unexpected } \\
\text { (\%) }\end{array}$ & $\begin{array}{c}\text { Undecided } \\
\text { (\%) }\end{array}$ & $\begin{array}{c}\text { Expected } \\
\text { (\%) }\end{array}$ & $\begin{array}{c}\text { Highly Expected } \\
\text { (\%) }\end{array}$ \\
\cline { 2 - 6 } & $2(.6)$ & $4(1.1)$ & $6(1.7)$ & $145(41.1)$ & $196(55.5)$ \\
\hline $\begin{array}{l}\text { Teachers will be responsive to the } \\
\text { students' questions }\end{array}$ & $1(.3)$ & $3(.9)$ & $8(2.3)$ & $158(45.1)$ & $180(51.4)$ \\
\hline $\begin{array}{l}\text { Teachers will provide proper } \\
\text { feedback to the students }\end{array}$ & $2(.6)$ & $1(.3)$ & $12(3.4)$ & $98(27.8)$ & $240(68)$ \\
\hline $\begin{array}{l}\text { Teachers should have good } \\
\text { communication skill }\end{array}$ & $13(3.7)$ & $12(3.4)$ & $48(13.6)$ & $168(47.6)$ & $112(31.7)$ \\
\hline $\begin{array}{l}\text { Teachers will do constructive } \\
\text { criticism to the students }\end{array}$ & $4(1.1)$ & $6(1.7)$ & $25(7.1)$ & $171(48.4)$ & $147(41.6)$ \\
\hline $\begin{array}{l}\text { Teachers will evaluate students the } \\
\text { way teacher taught them }\end{array}$ & $12(3.4)$ & $20(5.7)$ & $20(5.7)$ & $48(13.6)$ & $253(71.7)$ \\
\hline $\begin{array}{l}\text { Teacher will never reprimand } \\
\text { students for any reason }\end{array}$ & & & & & \\
\hline
\end{tabular}

Table 2 B: Table showed that maximum number of respondents expressed highly expected and expected in all the issues. Regarding statement about "Teacher will never reprimand students for any reason" 253(71.7\%) respondents expressed their views as highly expected.

$68 \%$ respondents expressed highly expected regarding teachers should have good communication skills and $48.4 \%$ respondents expressed expected regarding "Teachers will evaluate students the way teacher taught them.

"Teachers will be responsive to the students' questions" respondents in this issue expressed their views as highly expected and expected and the percentage was $55.5 \%$ and $45.1 \%$ respectively. 
Table 2. C: Distribution of the respondent by their opinion on the statements regarding expectations of students from their teachers in relation to teaching

\begin{tabular}{|c|c|c|c|c|c|}
\hline \multirow{2}{*}{$\begin{array}{l}\text { Statements regarding students' } \\
\text { expectations from their teacher in } \\
\text { relation to teaching }\end{array}$} & \multicolumn{5}{|c|}{ Level of Expectation } \\
\hline & $\begin{array}{l}\text { Highly Unexpected } \\
(\%)\end{array}$ & $\begin{array}{l}\text { Unexpected } \\
(\%)\end{array}$ & $\begin{array}{l}\text { Undecided } \\
(\%)\end{array}$ & $\begin{array}{c}\text { Expected } \\
(\%)\end{array}$ & $\begin{array}{l}\text { Highly Expected } \\
\text { (\%) }\end{array}$ \\
\hline $\begin{array}{l}\text { The environment of all lecture } \\
\text { classes will be easy congenial and } \\
\text { interesting }\end{array}$ & $2(.6)$ & - & $6(1.7)$ & $95(26.9)$ & $250(70.8)$ \\
\hline $\begin{array}{l}\text { Teachers will be impartial to all } \\
\text { students in all aspects }\end{array}$ & $2(.6)$ & - & $4(1.1)$ & $60(17)$ & $287(81.3)$ \\
\hline $\begin{array}{l}\text { Teachers will never be biased } \\
\text { irrespective of students' social } \\
\text { status }\end{array}$ & $3(.8)$ & - & $5(1.4)$ & $51(14.4)$ & $294(83.3)$ \\
\hline $\begin{array}{l}\text { Teachers will be impartial } \\
\text { irrespective of gender }\end{array}$ & $1(.3)$ & - & $7(2)$ & $45(12.7)$ & $300(85)$ \\
\hline $\begin{array}{l}\text { Teachers will be impartial } \\
\text { irrespective of religion }\end{array}$ & $3(.8)$ & - & $8(2.3)$ & $54(15.3)$ & $288(81.6)$ \\
\hline
\end{tabular}

Table 2. C: Table showed that 71 to $85 \%$ of all the respondents expressed their views as highly expected in all the issues. The maximum (85\%) number of the respondents expressed teacher should be impartial irrespective of gender. Moreover teachers should be impartial in all aspects.

$83.3 \%$ of the respondents viewed that teachers should not be biased irrespective of students' social status.

Among the respondents $97.7 \%$ (70.8+26.9) expressed their views as expected and highly expected regarding the statement of "The environment of all lecture classes will be easy congenial and interesting"

Table 3: Distribution of the respondent by their opinion on Statements regarding students' expectations from their teachers in relation to interpersonal relationship

\begin{tabular}{|c|c|c|c|c|c|}
\hline \multirow{2}{*}{$\begin{array}{l}\text { Statements regarding students' } \\
\text { expectations from their teachers in } \\
\text { relation to interpersonal relationship }\end{array}$} & \multicolumn{5}{|c|}{ Level of Expectation } \\
\hline & $\begin{array}{l}\text { Highly Unexpected } \\
(\%)\end{array}$ & $\begin{array}{l}\text { Unexpected } \\
(\%)\end{array}$ & $\begin{array}{l}\text { Undecided } \\
(\%)\end{array}$ & $\begin{array}{l}\text { Expected } \\
(\%)\end{array}$ & $\begin{array}{l}\text { Highly Expected } \\
\text { (\%) }\end{array}$ \\
\hline $\begin{array}{l}\text { Inter personal relationship between } \\
\text { students and teachers will be } \\
\text { congenial and friendly }\end{array}$ & $2(.6)$ & - & $7(2)$ & $131(37.1)$ & $213(60.3)$ \\
\hline $\begin{array}{l}\text { Inter personal relationship between } \\
\text { teachers will be good }\end{array}$ & $2(.6)$ & $1(.3)$ & $11(3.1)$ & $137(38.8)$ & $202(57.2)$ \\
\hline $\begin{array}{l}\text { Inter personal relationship between } \\
\text { students should be good }\end{array}$ & $1(.3)$ & & $7(2)$ & $141(40.2)$ & $202(57.5)$ \\
\hline $\begin{array}{l}\text { Teachers will never be angry with } \\
\text { the students in the class }\end{array}$ & $3(.8)$ & - & $3(.8)$ & $99(28)$ & $248(70.3)$ \\
\hline $\begin{array}{l}\text { Teachers will be supportive to the } \\
\text { needs of the students }\end{array}$ & $1(.3)$ & - & $4(1.1)$ & $106(30.1)$ & $241(68.5)$ \\
\hline $\begin{array}{l}\text { Students will get all types of } \\
\text { guidance and direction from their } \\
\text { teachers when we are under stress }\end{array}$ & $1(.3)$ & - & $10(2.8)$ & $109(30.9)$ & $233(66)$ \\
\hline $\begin{array}{l}\text { Teachers will be role model to the } \\
\text { students }\end{array}$ & $4(1.1)$ & $2(.6)$ & $13(3.7)$ & $144(40.8)$ & $190(53.8)$ \\
\hline $\begin{array}{l}\text { Teachers will have good professional } \\
\text { knowledge, teaching style and } \\
\text { interactive to the students }\end{array}$ & $3(.8)$ & $8(2.3)$ & $29(8.2)$ & $137(38.8)$ & $176(49.9)$ \\
\hline
\end{tabular}

Bangladesh Journal of Medical Education 2012;3(1):12-17. 
Table 3: Table showed the distribution of respondents regarding the statements on the expectations of students regarding interpersonal relationship of teachers with the students. $98.3 \%(70.3+28)$ respondents expressed their views as highly expected and expected regarding the statement on "Teachers will never be angry with the students in the class".

Regarding statement on "Inter personal relationship between students and teachers will be congenial and friendly" 213(60.3\%) respondents expressed highly expeced and 131(37.1\%) expressed expected total $97.4 \%$ expressed highly expected and expected.

In all the issues maximum number of respondents expressed their views as highly expected and expected. Regarding “ Students should get all types of guidance and direction from their teachers when we are under stress" 96.9\% respondents viewed highly expected and expected.

Regarding "Teacher as a role model" students expressed their views as highly expected $190(53.8 \%)$ and expected $144(40.8 \%)$.

Table 4: Distribution of the respondent by their opinion on Statements regarding students' expectations from their teacher in relation to use of instructional material by the Teachers

$\mathrm{n}=353$

\begin{tabular}{|c|c|c|c|c|c|}
\hline \multirow{2}{*}{$\begin{array}{l}\text { Statements regarding students' } \\
\text { expectations from their teacher in } \\
\text { relation to use of instructional } \\
\text { material by the Teachers }\end{array}$} & \multicolumn{5}{|c|}{ Level of Expectation } \\
\hline & $\begin{array}{c}\text { Highly Unexpected } \\
(\%)\end{array}$ & $\begin{array}{l}\text { Unexpected } \\
(\%)\end{array}$ & $\begin{array}{c}\text { Undecided } \\
(\%)\end{array}$ & $\begin{array}{c}\text { Expected } \\
(\%)\end{array}$ & $\begin{array}{c}\text { Highly Expected } \\
(\%)\end{array}$ \\
\hline $\begin{array}{l}\text { Teachers will be able to use properly } \\
\text { the multimedia, OHP in conducting } \\
\text { class }\end{array}$ & $3(.9)$ & & $4(1.2)$ & $145(41.8)$ & $195(56.2)$ \\
\hline $\begin{array}{l}\text { Teachers' will provide handout to the } \\
\text { students for effective conduction of } \\
\text { class }\end{array}$ & $2(.6)$ & & $14(4)$ & $151(42.8)$ & $186(52.7)$ \\
\hline $\begin{array}{l}\text { All teachers will be expert to used all } \\
\text { types of Instructional materials } \\
\text { including microphone and Audio - } \\
\text { visual system }\end{array}$ & $1(.3)$ & $1(.3)$ & $16(4.5)$ & $158(44.8)$ & $177(50.1)$ \\
\hline $\begin{array}{l}\text { Teachers will also use the traditional } \\
\text { instructional materials like black } \\
\text { board and white board }\end{array}$ & $6(1.7)$ & $24(6.8)$ & $63(17.8)$ & $144(40.8)$ & $116(32.9)$ \\
\hline $\begin{array}{l}\text { Teachers will use internet and all } \\
\text { types of available modern } \\
\text { technologies for better understanding } \\
\text { of the students in the class }\end{array}$ & & & & $162(45.9)$ & $191(54.1)$ \\
\hline
\end{tabular}

Table 3: Table showed the distribution of the respondent by their opinion on Statements regarding students' expectations from their teacher in relation to use of instructional material by the Teachers. In all the issues $>90 \%$ respondents expressed their views highly expected and expected except the statement on "Teachers will also use the traditional instructional materials like black board and white board". Only $73.7 \%$ respondents expressed highly expected and expected which is also very high.

$100 \%$ respondents expressed their views regarding the statement "Teachers will use internet and all types of available modern technologies for better understanding of the students in the class" as highly expected 191(54.1\%) and expected 162(45.9\%).

* There was no significant difference or variations in expectations among the medical colleges.

\section{Discussion}

Little attention appears to have given to students' expectation. The real value of this approach appears to be that it is a simple and inexpensive way to determine what student expect from the teachers. In this study 353 students participated from three selected medical colleges in Bangladesh. Almost all the statements in the three aspects expectation of the students were very high. As per DREEM, 50 statements were analyzed. Students' perception of Learning, perception of teachers' and students' perceptions of atmosphere were the main aspects of 50 statements. In this study, only 30 statements were included on teaching, interpersonal relationship and on instructional material used by the teachers. In the study it was found that expectations of

Bangladesh Journal of Medical Education 2012;3(1):12-17. 
students were high in all the statements. Susan Miles and Sam Lister in their study with a version of the DREEM, asking students to think about what they expected their first year with respect to their expected perceptions. They found students perception of learning was that the teaching would be highly thought of (scores of 37-48) and their perception of the teachers was that they would be model teachers (Score of 34-44). In this present study, regarding on the statement of sincerity in imparting teaching were highly expected by $263(74 \%)$ and expected $83(23.5 \%)$ respondents \& Regarding statement of Teacher will be role model to the students' 334(94.6\%) respondents expressed expected and highly expected. Health care educators have long used simulations to enhance safely. In recent years, interest has grown in examining students' expectations and perception of the educational environment since these are in many ways related to students' behaviour, academic achievement satisfaction and aspiration. Simulation potentially provide a safe and realistic learning environment in which repeated practice is possible. In the study of students expectations of the learning process in simulation based environment by Tuulikki K. found that expectation of students of teaching in vertical Reality \& simulation based learning environment were quite high (49.5\%) and most often, student expected that teaching would help to develop their competence.
In this study on the statement of Teachers will use internet and all types of available modern technologies 100\% respondent expressed expected and highly expected.

In this study in Bangladesh context especially in the selected three medical colleges the level of expectations of male and female students were similar. They both expect better Teaching good knowledge, good interpersonal relationship and use of modern technology as instructional material by the teachers.

\section{Conclusion}

Students' expectations are not an easy issue to deal with since they may not only depend on the teachers and administrators but also on individual students as well, Therefore ore research needs to be done in this issue in order to provide answers to some questions. Considering the results of different issues regarding expectations of the students this study would be very helpful to the teachers and administrators to take necessary measures to address the issues by which overall improvement of educational outcome can be achieved.

Bangladesh Journal of Medical Education 2012;3(1):12-17. 